\title{
Insight
}

\section{A Revised Conceptual Framework for Payments for Environmental Services}

\author{
$\underline{\text { Matthew M. Sommerville }}^{1}, \underline{\text { Julia P. G. Jones }}^{2}$, and E. J. Milner-Gulland $^{1}$
}

\begin{abstract}
Over the past decade, "Payments for Environmental Services" (PES) have received a great deal of attention as a natural-resource management approach. We propose a revised definition and framework for PES implementation that focuses on the use of positive incentives as the philosophy behind PES and conditionality as the method for influencing behaviors. We note the importance of additionality of PES interventions to justify their value in a wider context. Finally, we highlight the need to understand the local institutional context in terms of the characteristics of buyers, sellers, and their relationship for implementation to be effective. Our framework acts as a platform to begin examining how the variety of options for structuring PES projects can be adapted to a range of existing institutional contexts.
\end{abstract}

Key Words: additionality; conditional; ecosystem services; environmental management; incentives; institutions; monitoring; transactions

\section{INTRODUCTION}

Ecosystems provide valuable services to local, regional, and international communities (Costanza et al. 1997, Millenium Ecosystem Assessment (MEA) 2005). However, traditional markets are underdeveloped or lacking for many environmental services such as watershed benefits, biodiversity conservation, and carbon sequestration. As a result, decisions to convert or alter natural habitat toward market-based agricultural or timber activities generally fail to take into account the total costs of service loss (Westman 1977, Hanley 1992, Loomis et al. 2000). Where these services are of direct, indirect, or nonuse value to neighboring or distant communities, the internalization of these external values may tip the scales in favor of environmentalservice provision, particularly if competing resource uses, such as agriculture or timber, are only marginally profitable (Pearce and Moran 1994, Pagiola et al. 2004). To this end, "Payments for Environmental Services" (PES) (also called ecosystem or ecological services) have emerged over the past decade. The term acts as an umbrella for approaches that provide positive incentives to manage ecosystems to produce environmental services (Simpson and Sedjo 1996, Landel-Mills and Porras 2002). These incentives may be put in place to compensate those presently providing an environmental service or to incentivize those who would otherwise not provide the service.

Despite the emergence of PES as a set of tools, the definition of PES has been for the most part implicit. However, a recent definition by Wunder (2005, 2006, 2007) has received widespread acceptance from the academic community (articles cited more than 150 times between January 2005 and December 2008, according to Google Scholar) as well as from practitioners of payment interventions, such as the Center for International Forestry Research (CIFOR) and the Katoomba Group's Ecosystem Marketplace. Wunder classifies PES as (1) voluntary transactions where (2) a well-defined environmental service (ES) is (3) being "bought" by a minimum of one ES buyer (4) from a minimum of one ES provider, (5) if and only if the ES provider secures ES provision (conditionality). Those who have evaluated PES interventions in practice have found that most interventions attempting to implement PES do not meet all of these criteria. For example, perhaps the most well known tropical PES 
program, Costa Rica's countrywide "Pagos por Servicios Ambientales" (PSA), would not be considered a pure PES approach by Wunder's definition, given that payments from some user groups are nonvoluntary (Pagiola 2008). Swallow et al.(2007) present their discomfort with the current definition:

(W)e do not challenge the Wunder definition of PES per se, but do doubt its usefulness for describing and analyzing the range of interesting and important mechanisms that are being negotiated for managing interactions between people with diverse interests in ecosystem management and ecosystem services.

In order to deal with these various contexts, there have been a number of attempts to develop an alternative vocabulary to PES, such as "Compensation and Rewards for Ecosystem Services" (CRES) (Swallow et al. 2007), or subcategories of PES, like "Markets for Ecosystem Services" (MES) (Pagiola and Platais 2002) and "International Payments for Environmental Services" (IPES) (UNEP et al. 2006). Nevertheless, PES remains the most widely used and recognized term.

There is wide acknowledgement that because of the variety of local institutional contexts surrounding natural-resource management, pure PES approaches fulfilling all of the criteria may not always be possible, or even preferable (Wunder 2005, Corbera et al. 2007, Engel and Palmer 2008). As a result, whether a project can be considered a PES intervention is frequently a gray area. For example, Wunder et al. (2008) describe South Africa's "Working for Water" program as a "PES-like" program due to the fact that those being paid are not necessarily the de jure or de facto landowners. In contrast, the same article considered China's "Sloping Lands Conversion Program" to be a PES program, despite participation frequently being involuntary (Bennett 2008, Wunder et al. 2008).

It becomes a judgment call as to whether several individual programs should be considered "PES with qualifications," or "non-PES with PES-like characteristics"... Even among us three editors, there is thus some disagreement over where exactly the line between PES and non-PES should be drawn (Wunder et al. 2008).

There is a risk that the use of terms such as "PES with qualifications" or "PES-like" implicitly suggests that interventions not fulfilling all of the definition's criteria are inferior. We believe that "PES" is best seen as an umbrella term for a set of resource-management tools that are based on the philosophy of implementing conditional positive incentives in a wide variety of institutional contexts. Therefore, we suggest a revised framework for PES that focuses on two core criteria forming a definition of PES and two additional principles to guide planning and implementation.

\section{A Revised Framework}

We propose a definition of PES that does not relax Wunder's (2005) definition, but rather refines and refocuses it on the two criteria that we believe make PES a unique and powerful set of approaches for ecosystem management. We define PES as approaches that aim to (1) transfer positive incentives to environmental service providers that are (2) conditional on the provision of the service, where successful implementation is based on a consideration of (1) additionality and (2) varying institutional contexts.

We consider four of Wunder's five criteria to be present within our framework, yet only the conditional criterion is common to both (Table 1). We do not argue that a well-defined service, and buyers and service providers, are not important to PES, but rather that they are implicit within the criterion of conditionality and are best considered as part of the institutional context. The one criterion that we believe is not crucial to all PES interventions is that they must be voluntary. Although we agree that PES are voluntary at the level of the transaction (i.e., service providers can decide whether or not to accept payment), service providers do not necessarily have the choice whether or not to provide the service, such as in cases where land-use change is illegal. Instead, we propose that the extent to which a PES intervention is voluntary belongs within the discussion of institutional contexts. We believe our framework offers the flexibility for practitioners and academics to develop specific tools for varying situations, but retains a grounding 
Table 1. Comparative list of the criteria for PES from Wunder (2005) and of criteria and considerations from this paper with justifications for the changes made in this paper.

\begin{tabular}{|c|c|c|}
\hline This paper & Wunder & Justification for differences between definitions \\
\hline \multicolumn{3}{|l|}{$\underline{\text { Criteria }}$} \\
\hline conditionality & conditionality & $\begin{array}{l}\text { Methodological core of both definitions that incorporates monitoring and the } \\
\text { definition of the service goal. }\end{array}$ \\
\hline $\begin{array}{l}\text { positive } \\
\text { incentives }\end{array}$ & & $\begin{array}{l}\text { Ideological core to both definitions and implicit in Wunder's; is also implicit in the } \\
\text { use of the term "payment" as opposed to fines, although positive incentives are not } \\
\text { limited to monetary transfers. }\end{array}$ \\
\hline \multicolumn{3}{|l|}{ Considerations } \\
\hline additionality & & $\begin{array}{l}\text { Reflective of the social or ecological goals of the intervention and allows wider } \\
\text { impact to be measured. Discussed by Wunder but not a criterion. }\end{array}$ \\
\hline \multirow[t]{5}{*}{$\begin{array}{l}\text { institutional } \\
\text { context }\end{array}$} & & $\begin{array}{l}\text { Practical implementation issues that will vary among PES interventions, implicit in } \\
\text { Wunder's discussion of buyers, service providers, voluntary and PES-like } \\
\text { interventions. }\end{array}$ \\
\hline & voluntary & $\begin{array}{l}\text { Falls within a consideration of institutional context, as the voluntary criterion may be } \\
\text { met to varying degrees within a conditional positive incentive. }\end{array}$ \\
\hline & $\begin{array}{l}\text { well-defined } \\
\text { service }\end{array}$ & Implicit in the concept of conditionality. \\
\hline & buyer & $\begin{array}{l}\text { Implicit in the idea of a transfer and fits better as a component of the institutional } \\
\text { context. }\end{array}$ \\
\hline & service provider & Same as for buyers. \\
\hline
\end{tabular}

in the spirit and methodology of PES. Below, we elaborate on the two core criteria, evaluate policy tools based on these two criteria, and explore the roles of additionality and institutional contexts in the implementation of PES.

\section{CRITERIA FOR PES}

\section{Positive Incentives}

The use of positive incentives, including (but not limited to) payments, is the core ideology of PES. We differentiate between positive and negative incentives and discuss the use of positive incentives in PES to impact both behaviors and attitudes. We also elaborate on the need to consider the distributional impacts of implementing positive incentives at a range of scales, as well as the role of negative incentives and an overemphasis on monetary payments in current PES literature.

Incentives are factors that influence a decision maker's motivation to engage in an action. We classify incentives as positive or negative based on whether a decision maker perceives a gain or loss from their baseline. A PES scheme should aim to provide a net gain for participants through the use of positive incentives. Most commonly, this involves a material compensation or reward for individuals, based on opportunity costs incurred by stopping a behavior that is detrimental to service delivery, or for taking actions to increase or maintain service delivery.

In the most straightforward PES approach, individuals possess legal control over the service provision (e.g., they have the right to carry out 
certain land-use changes that would change service provision) and incentives are transferred to influence the decision to produce the service. Indeed, in this case, the implementing organization or user group is constrained to using positive incentives, as there may be no legal justification for negative incentives. This context is particularly common when individuals are paid to implement certain farming practices, such as to develop or maintain hedgerows under agri-environment schemes (Dobbs and Pretty 2008). This is also the case in most user-financed PES schemes, where downstream water users create incentives for upstream landowners to safeguard water quality through particular land-management practices.

Positive incentives may also be used in a PES program to influence attitudes toward a regulation or a change in legal enforcement. For example, Pagiola (2008) suggests that a primary reason behind the establishment of Costa Rica's PSA was to make a legislative ban on deforestation on private lands more palatable to landowners and to entice them to cooperate. In these circumstances, the PES system does not drive the change in behaviors. Nevertheless, it is important for achieving social support that may ultimately strengthen compliance with the anti-clearance law.

The issue of the scale at which the positive incentives need to be felt for an intervention to be classified as a PES approach needs careful consideration. For example, if payments are made to a regional or central government, rather than to individuals making the resource-use decisions, then positive incentives may not be driving provision of services on the ground, although they drive the decision of the government to participate. This is the case within the nationally managed system of Conservation International's Guyana conservation concessions, where payments are made to the government to offset logging opportunity costs (Hardner and Rice 2002). Although this may be considered a PES intervention at the national level, the government may use a variety of negative incentives to ensure local compliance. In such situations, a PES intervention may appear to local people to be little different from traditional lawenforcement approaches. This issue may become particularly relevant as the "Reduced Emissions from Deforestation and Forest Degradation" (REDD) methodologies are put into practice under the United Nations Framework Convention on
Climate Change, as emissions credits are likely to accrue at the national level. Even where incentives are targeted at the community level, distributional issues at the village level may mean that some community members do not receive benefits but that compliance is obtained by coercion from within the community (Grieg-Gran et al. 2005, Pagiola et al. 2005). Such examples muddy the consideration of Wunder's voluntary criterion and project funders may have to decide whether it is possible or even preferable to be concerned with the ultimate distribution of benefits once the payments are made. Nevertheless, it is clear that positive incentives must be driving the participation at the level of the transaction, and that for a scheme to reflect the spirit of PES, there should be an explicit attempt to transfer these positive incentives down to the individual providing the service. Indeed, such concerns are being addressed in the development of REDD methodologies, as safeguards are likely to be implemented to ensure that REDD has local-level benefits (Peskett et al. 2008).

A dedication to positive incentives does not imply the absence of negative incentives within the framework of a PES intervention. When payments are used to influence attitudes and participation in a regulatory environment, the repercussions associated with regulation act as a negative incentive. Negative incentives may also emerge from PES systems through coercion to participate based on social pressure from other community members, or even through regulatory fines and punishments. Nevertheless, by definition, the positive incentives should outweigh the negatives for those participating in a PES intervention.

The role of monetary payments as positive incentives needs to be considered in the design of PES interventions. Payments have been shown to act as negative incentives under some circumstances, because small payments can insult participants and, therefore, can lower the motivation of individuals, or payments can "crowd out" other pre-existing forms of motivation such as altruism (Gneezy and Rustichini 2000, Frey and Jergen 2001). Similarly, there is cause for concern in terms of diminishing returns through time from the repeated use of positive incentives (Benebou and Tirole 2003). Over time, positive incentives may become perceived not as incentives but as entitlements, and thus lose their motivational force. 
Finally, there has been an overemphasis on monetary payments within the general PES discourse that frequently settles on the term "payments," and the monetary transfers this implies. Because the aim of PES is to influence the behaviors of those who have some control over service provision, the impact of positive incentives other than payments should be considered. Indeed, individuals rarely act as pure profit maximizers (Frank 1987), with social cooperation, local norms, or religious beliefs also influencing behavior (Deci and Ryan 1985, Heinrich et al. 2001, Ajzen and Fishbein 2005). Therefore, positive incentives may come from social impacts such as tenure legitimacy and pride, in addition to monetary transfers. This highlights the need to evaluate the roles and interactions of a range of potential positive and negative incentives throughout an intervention's lifespan. For example, the complex interactions of monetary payments with other positive and negative incentives have been apparent in PES schemes when individuals choose to provide services at payments lower than their opportunity costs (Wunder 2005, Kosoy et al. 2007).

\section{Conditionality}

Conditionality is the core method for motivating service provision, as it creates a consequence for not providing the service. The use of conditionality also makes the definition of the service, the monitoring regime, and the enforcement explicit to the buyer and service provider. Therefore, this term subsumes Wunder's criteria of conditionality and a well-defined service, and places a focus on the issue of monitoring.

The decision as to whether to make incentives conditional on measurements of the service itself or of the actions taken by providers is an important one for those designing PES interventions (Engel et al. 2008). Deciding which approach to take relates primarily to the technical challenges and costs of monitoring. Because of the difficulties of measuring changes in environmental services, payments are often conditional on ecological indicators with assumed relationships to service provision, rather than based on the flow of the service itself. For example, carbon service provision may be estimated by monitoring coarse changes in habitat that can be observed remotely by satellites (Sanchez-Azofeifa et al. 2007). Alternatively, because PES interventions seek to change behaviors, payments conditional on specific actions of service providers are also common. European agri-environmental biodiversity payments are based on the assumed relationships between actions and environmental outputs, such as the creation of hedgerows and biodiversity, rather than payments for delivery of directly measured environmental benefits (Glebe 2007, Dobbs and Pretty 2008). Such action-based agreements increase the farmer's and policy maker's certainty concerning what they will pay and receive. However, they increase uncertainty associated with ecological outcomes (Kleijn et al. 2004). Thus, the most appropriate monitoring to employ depends on the capacity to observe the service, the capacity to observe the actions or effort of the service providers, and the strength and consistency of the relationship between the providers' actions and service provision.

It is not only what is monitored that impacts the efficacy and cost effectiveness of conditionality, but also who monitors. The most cost-effective schemes are likely to have a structure where the service provider has an incentive to truthfully monitor and report their own actions (Laffont and Tirole 2001). Alternatively, in systems where service delivery is contingent on multiple resource-management units, monitoring by peers may be effective. The most challenging monitoring regimes force service buyers to monitor diffuse services where individual shirkers cannot be easily identified. In such cases, for a scheme to adequately incentivize individuals, an entire group of service providers may have to bear the cost of a single individual's noncompliance (Meijerink 2008). These costs may mean that payments stop flowing to the service provider, or that the provider incurs a fine. Social disapproval may also play an enforcement role in group schemes. It is critical to understand how various structures of monitoring and enforcement impact intervention success. The wide range of these issues is best dealt within a consideration of institutional contexts. Nevertheless, conditionality is undoubtedly a central criterion that is critical to the functioning of PES schemes.

\section{EVALUATION OF INCENTIVE STRUCTURES}

Our framework does not create an unambiguous line separating various policy tools. Although interventions that rely on negative incentives (such as fines and regulation) clearly do not fall under 
PES, some policy tools fulfill the PES criteria more often than others. Policies that rely on positive incentives for service provision, such as integrated conservation and development projects (ICDPs), ecological certification, quota-based trading systems, transferable development rights, and government subsidies, may require a nuanced evaluation to determine whether they qualify.

Integrated conservation and development projects are one of the most common approaches in international conservation, but they generally do not fit the PES criteria. This is primarily because the payments are not explicitly conditional on the provision of service benefits (Ferraro 2001). Furthermore, making development benefits (such as access to health and education or construction of facilities for public use) conditional on service provision may be morally unacceptable.

We do not consider certification or ecolabeling to constitute PES approaches, as there is no assured relationship between certification and a positive incentive (Sedjo and Swallow 2002). Although the objective is an incentive in the form of higher price for certified goods, it is not guaranteed and it depends on a market being available. In contrast, schemes that provide a guaranteed-price premium to service providers for the provision of an ES would be considered a PES approach.

Many markets for environmental services, such as the European trading system for carbon, or tradable harvest quotas for fish or game species, would not be classified as PES interventions. An environmental service is provided by a regulation that caps emissions or harvesting. However, in these cases, trading becomes a mechanism to ensure an efficient distribution of rights (Tietenberg 2003).

Within the international climate regime, the likely implementation of REDD will act as a PES approach where governments become the primary buyers and providers (Ebeling and Yasue 2008). As implementation on the ground is likely to be devolved in many countries to NGOs, they may also use REDD funds from the government to implement local-level PES schemes. However, it is not clear whether the national and subnational-level activities under REDD will necessarily fulfill PES criteria. In contrast, the Clean Development Mechanisms and Joint Implementation Procedures pass PES criteria in theory, as incentives are transferred based on discrete, measurable, and additional reductions in carbon emissions (Streck 2004).

Conservation easements, and indeed, any intervention where one-time property rights are transferred to another group, would not likely be considered PES approaches because once the rights are transferred, the new owner of the rights becomes the service provider. However, there may be an implied relationship between two policy interventions. For example, conservation easements are frequently implemented along with preferential tax assessments, whereby preferential taxes are given to land that has easements on it. A preferential tax assessment based on environmental-service provision would be an unambiguous PES system, but the presence of an easement simply represents a way of targeting landowners who are more likely to provide a service. A similar example can be observed in the U.S. Fish and Wildlife Service (USFWS) ConservationBanking Program. Conservation-banking systems typically use trust funds to finance annual management of habitats for environmental services and would thus be considered PES (USFWS 2009). However, similar to preferential tax assessments, the USFWS incorporates an eligibility prerequisite that land must be under a development easement.

Governments are frequently purchasers of environmental services through subsidies for environmental-service production, for example in European Union (EU) agri-environment schemes (Dobbs and Pretty 2008). In these cases, payments are linked to actions undertaken by farmers. Yet, the role of governments in PES interventions may be complicated because the range of government resource-management policies may or may not be perceived as separate from one another. This is particularly acute in programs such as the U.S. Conservation Reserve Program (CRP) where one of the explicit goals, alongside the ecological goals of preventing erosion and creating habitat, was to "provide needed income support for farmers" (Reichelderfer and Boggess 1988). Indeed, because positive incentives drive our framework for examining PES, whether or not an incentive scheme acts as a PES approach may be contingent on how a government portrays the policy. 


\section{PES CONSIDERATIONS}

Although conditional positive incentives are the defining characteristic of PES, in practice, there are additional considerations that influence the ultimate success of an intervention. In particular, a consideration of additionality provides assurance to investors that an intervention will have a measurable impact, but a consideration of the institutional context surrounding implementation ensures that the specific design of a PES intervention is appropriate. It is not within the scope of our work to fully elaborate on these considerations. However, we will draw out their relevance to PES and highlight areas that are particularly controversial.

\section{Additionality}

Whereas conditionality allows one to demonstrate the impact of an intervention (i.e., whether the service provider has met the conditions of the agreement), additionality is the measure of outcomes in relation to what would have occurred in the absence of the intervention. Therefore, additionality is of equal or greater interest to funders and the wider community, as it is essential for assessing intervention impacts (Engel and Palmer 2008). A number of PES evaluations have determined post hoc that they have achieved relatively little, if any, behavioral or ecological additionality (Sanchez-Azofeifa et al. 2007, Munoz-Pina et al. 2008). Wunder highlights the importance of additionality in his discussion of PES, although he does not include it into his defining criteria (Wunder 2007). Although we agree that additionality is not a defining criterion for an intervention to be a PES approach, it should be an aspiration for all environmental-management interventions.

Additionality is a central criterion for the most developed environmental-service markets for carbon (Pfaff et al. 2000, Niesten et al. 2002), and it is frequently used as an indicator of PES effectiveness (Engel and Palmer 2008, Wunder et al. 2008). Unfortunately, it is extremely difficult to demonstrate additionality due to the methodological and practical challenges of estimating baselines, measuring the service itself, and identifying leakage (Aukland et al. 2003). With respect to leakage, for example, $\mathrm{Wu}$ (2000) demonstrated that for every
100 acres (40.5 ha) of cropland taken out of production by the CRP, 20 acres ( 8.1 ha) were brought into production, resulting in fewer benefits than advertized. We suggest that the spatial and temporal scales at which an intervention will be additional should be considered in advance of PES interventions, allowing investment opportunities to be compared. Nevertheless, it is clear that due to the challenges of establishing additionality, in many cases, these estimates will be qualitative at best.

There may be cases where ecological additionality is not a feasible objective for each participant in a PES intervention. Because of targeting difficulties, or due to social equity or political goals, it may not be possible to pay only those whose supply of the service is likely to depend on the payment. Information on the likely supply of a service in the absence of payments may be difficult or costly to obtain. There are techniques to target payments in the absence of such information (Ferrraro 2008, Wunscher et al. 2008, Barton et al. 2009), but this is costly and often requires large amounts of data. Some concern has been raised that targeting payments too narrowly on those likely to produce true additionality may create perverse incentives (Pirard and Karsenty 2009). For example, if payments are made only to landholders who are thought likely to convert their land, this may encourage increased land conversion by others. These issues should be explicitly acknowledged in the planning stages to avoid unrealistic expectations of the ecological or social impacts of a PES intervention. Although we consider additionality to be infeasible as a defining criterion of PES schemes, it must be a guiding consideration to ensure that it does not become acceptable to infuse substantial funds into communities as incentives without concern for what has been achieved (Ferraro and Pattanyak 2006).

\section{Institutional Context}

Although our two criteria define the essence of a PES intervention, it is the institutional structure that guides the practice and ultimate effectiveness of an intervention (Engel and Palmer 2008, Corbera et al. 2009). PES opportunities do not only exist within the narrow confines of voluntary transactions between buyers and providers. Instead, there are a wide variety of situations where environmental- 
Table 2. Nonexhaustive list of institutional contexts under which PES may be implemented. Characteristics on the left side of the options are generally (although not always) easier contexts for implementing PES. These choices often rest within a continuum rather than a dichotomy.

\begin{tabular}{|c|c|c|c|c|}
\hline Characteristics & Institutional context & & Option & \\
\hline \multirow{5}{*}{$\begin{array}{l}\text { Service } \\
\text { provider }\end{array}$} & governance type & democratic & vs. & authoritarian \\
\hline & type of provider & individual & vs. & community \\
\hline & property tenure & private property & vs. & no tenure \\
\hline & legality of behaviors & legal & vs. & illegal \\
\hline & opportunity costs & homogenous & vs. & variable \\
\hline \multirow[t]{3}{*}{ Buyer } & buyer's funding & secure & vs. & insecure \\
\hline & buyer goals to trade-off & economic efficiency & vs. & equitable distribution \\
\hline & additional buyer goals to trade-off & social & vs. & ecological \\
\hline \multirow[t]{5}{*}{ Relationship } & threats to system & internal & vs. & external \\
\hline & $\begin{array}{l}\text { distance between buyer and } \\
\text { provider }\end{array}$ & local & vs. & international \\
\hline & $\begin{array}{l}\text { relationship between buyer and } \\
\text { provider }\end{array}$ & one-on-one & vs. & intermediaries \\
\hline & negotiations & market-based & vs. & $\begin{array}{c}\text { one-off/project-based } \\
\text { negotiation }\end{array}$ \\
\hline & participation constraints & voluntary & vs. & regulated \\
\hline
\end{tabular}

service suppliers and buyers can operate. As a result, interventions frequently diverge from Wunder's criteria based on these constraints. They may be generally organized in terms of characteristics of the buyers, service providers, and the relationship between the two, and expressed through a series of dichotomies (Table 2). We cannot elaborate here on each of the contexts. Rather, we will highlight key issues and identify case studies where specific institutional issues have been considered.

\section{Buyer and service provider characteristics}

We consider the existence of buyers and service providers of environmental services to be implicit within the two defining criteria. Yet, the wide variety of buyers and providers and their potential relationships are important to consider in the design of a PES intervention. Choosing the most appropriate provider may be of interest, for example, when multiple providers have legitimate claims to a single service. This may be the case when local community members have customary rights on government property. As a result, it is not always immediately clear whether payments should be made to individuals, the community, or government. For example, within a biodiversity PES intervention in Menabe, Madagascar, payments are made to communities with customary rights (Durbin 2002), whereas in Guyana, payments 
are made to influence national-government priorities (Hardner and Rice 2002). In each case, the service buyer made a decision as to which service provider it believed to be the most effective institution to negotiate with. Had the Madagascar NGO decided to negotiate with the central government, it is unlikely that management information and benefits would have effectively trickled down to the local communities, and it is unlikely that the PES would have been effective (Richard Lewis, pers. comm.).

\section{Relationship characteristics}

Within an agreement between two or more parties, there are a wide variety of characteristics that can describe the relationship. These can relate to spatial, temporal, legal, and power components of the relationships. Although the voluntary nature of an agreement has been used as a defining characteristic of PES interventions, this criterion is frequently not met in interventions commonly considered as PES (Robertson and Wunder 2005) and there are many examples where payments are used to alter behaviors that are already illegal.

A nonvoluntary PES approach may also be applicable where national-level enforcement of laws is limited and third-party organizations have a presence. In these cases, individuals can engage in PES voluntarily. However, they do not have the right to break the law. In Menabe, Madagascar, implementing a community-based biodiversity PES intervention has given Durrell Wildlife Conservation Trust a rationale for monitoring illegal forest-use behaviors. This has both acted as a direct deterrent and has stimulated the creation of local forestmonitoring councils to influence individual forestuse behaviors (Matthew Sommerville, pers. obs.). This approach has the added benefit of filling an institutional void left by limited government presence in the region and demonstrating the capacity for PES to complement the deficiencies in existing enforcement regimes.

Finally, the concept of a voluntary transaction is complicated in cases where PES are negotiated among collective groups at scales from small organizations to national governments. In such cases, the views of disadvantaged minorities within the community may be discounted (Corbera et al. 2007). As a result, although a PES intervention may be overtly voluntary, in reality, certain subgroups may be participating due to coercion. Whether all those affected by a PES intervention participate voluntarily depends on who can most effectively exert control over the services of interest and who is in a position to negotiate (Engel and Palmer 2008).

\section{How PES characteristics can be adapted to the institutional context}

The issues highlighted here describe some of the institutional characteristics that project developers may encounter. However, practitioners have choices in structuring the positive incentives, conditional methodology, and consideration of additionality that allow them to adapt to these institutional constraints and opportunities. The PES literature has begun to explore many of these structural choices based on early experience with PES tools. However, a great deal of applicable research has already been performed in the disciplines of economics, sociology, and management theory to guide this learning process (Laffont and Martimort 2002) (Table 3).

\section{CONCLUSION}

Payments for Environmental Services are widely promoted as a novel set of tools for environmental management. Wunder's definition has helped to structure academic and practitioners' thinking about this novel approach to conservation. Our modified framework has developed this definition and focused on the two principles that define the PES approach: positive incentives and conditionality. We have highlighted the novelty of the PES approach, and have been inclusive of a wide range of situations. A commitment to positive incentives in motivating resource-use decision making is the ideological basis for PES. The methodological core is based on making these incentives conditional on monitored provision of a service. The demonstration of benefits additional to those that would have occurred without the intervention represents an aspiration for PES interventions. The variety of institutional contexts informs planning and implementation. By making the definition of PES more inclusive and representative of realities on the ground, we have focused attention on the core principles of this approach. We hope that this revised framework provides a useful point of departure for future theoretical and practical work in the field of PES. 
Table 3. Examples of some aspects of PES design that may be modified in order to address local institutional constraints.

\begin{tabular}{|c|c|c|c|c|c|c|}
\hline \multirow{2}{*}{$\begin{array}{l}\text { Potential design } \\
\text { characteristics } \\
\text { Incentive type }\end{array}$} & \multirow{2}{*}{$\begin{array}{c}\text { Criterion/ } \\
\text { consideration } \\
\begin{array}{c}\text { positive } \\
\text { incentive }\end{array}\end{array}$} & \multicolumn{3}{|c|}{ Example } & \multirow{2}{*}{$\begin{array}{l}\text { PES studies that raise } \\
\text { these design } \\
\text { characteristics } \\
\text { Wunder 2005, Asquith } \\
\text { et al. 2008, Engel et al. } \\
2008\end{array}$} & \multirow{2}{*}{$\begin{array}{l}\text { Other studies that } \\
\text { examine these } \\
\text { characteristics } \\
\text { Currie 1994, Currie and } \\
\text { Ghavari } 2008\end{array}$} \\
\hline & & cash & vs. & in-kind & & \\
\hline Contract type & conditionality & $\begin{array}{l}\text { formal } \\
\text { contract }\end{array}$ & vs. & $\begin{array}{l}\text { implied } \\
\text { agreement }\end{array}$ & & Levin 2003 \\
\hline Payments based on & conditionality & $\begin{array}{l}\text { defined } \\
\text { actions }\end{array}$ & vs. & $\begin{array}{l}\text { state of } \\
\text { system }\end{array}$ & $\begin{array}{l}\text { CREC and CJC } \\
\text { Consulting 2002, } \\
\text { Musters et al. 2001, } \\
\text { Engel et al. } 2008\end{array}$ & $\begin{array}{l}\text { Baker et al. 1988, } \\
\text { Holmstrom and Milgrom } \\
1991\end{array}$ \\
\hline $\begin{array}{l}\text { Size of payment } \\
\text { based on }\end{array}$ & conditionality & $\begin{array}{l}\text { performance } \\
\text { relative to } \\
\text { others }\end{array}$ & vs. $\mathrm{i}$ & $\begin{array}{l}\text { individualized } \\
\text { specific } \\
\text { criteria }\end{array}$ & & $\begin{array}{l}\text { Nalebuff and Stiglitz } \\
\text { 1983, Malcomson } 1984\end{array}$ \\
\hline $\begin{array}{l}\text { Monitoring } \\
\text { (personnel) }\end{array}$ & conditionality & local agents & vs. & hired agents & Pagiola 2008 & $\begin{array}{l}\text { Holmstrom 1979, Frey } \\
\text { 1993, Cowen and Glazer } \\
1996 \text {, Gibson et al. } 2005\end{array}$ \\
\hline $\begin{array}{l}\text { Monitoring } \\
\text { (method) }\end{array}$ & $\begin{array}{l}\text { conditionality/ } \\
\text { additionality }\end{array}$ & on-ground & vs. & remotely & & \\
\hline $\begin{array}{l}\text { Payment time } \\
\text { horizon }\end{array}$ & $\begin{array}{l}\text { conditionality/ } \\
\text { additionality }\end{array}$ & annually & vs. & $\begin{array}{c}\text { end of } \\
\text { agreement }\end{array}$ & $\begin{array}{l}\text { Marland et al. 2001, } \\
\text { Wunder 2005, Peskett et } \\
\text { al. } 2008\end{array}$ & \\
\hline $\begin{array}{l}\text { Openness of } \\
\text { incentives (spatial) }\end{array}$ & additionality & inclusive & vs. & targeted & $\begin{array}{l}\text { Watzold and Dreschler } \\
\text { 2005, Barton et al. } \\
\text { 2008, Wunscher et al. } \\
2008\end{array}$ & \\
\hline $\begin{array}{l}\text { Openness of } \\
\text { incentives } \\
\text { (participation) }\end{array}$ & additionality & inclusive & vs. & targeted & Ferarro 2008 & van de Walle 1998 \\
\hline
\end{tabular}


Responses to this article can be read online at: http://www.ecologyandsociety.org/voll4/iss2/art34/ responses/

\section{Acknowledgments:}

We are grateful for discussions with Richard Lewis and Joanna Durbin, and comments from Sven Wunder. We would also like to acknowledge the insights offered by two anonymous reviewers. This work was funded by the Leverhulme Trust grant, F/07 058/AH, "Optimizing monitoring as a conservation tool," and by a Royal Society Wolfson Research Merit award to EJMG.

\section{LITERATURE CITED}

Ajzen, I., and M. Fishbein. 2005. The influence of attitudes on behaviors. Pages 173-222 in D. Albarracin, B. Johnson, and M. Zanna, editors. The handbook of attitudes. Routledge, New York, New York, USA.

Asquith, N. M., M. T. Vargas, and S. Wunder. 2008. Selling two environmental services: in-kind payments for bird habitat and watershed protection in Los Negros, Bolivia. Ecological Economics 65:675-684.

Aukland, L., P. Moura Costa, and S. Brown. 2003. A conceptual framework and its application for addresing leakage on avoided deforestation projects. Climate Policy 3:123-136.

Baker, G. P., M. C. Jensen, and K. J. Murphy. 1988. Compensation and incentives: practice vs. theory. The Journal of Finance 43:593-616.

Barrett, C. B., and P. Arcese. 1995. Are Integrated Conservation-Development Projects (ICDPs) sustainable? On the conservation of large mammals in subSaharan Africa. World Development 23:1073-1084.

Barton, D. N., D. P. Faith, G. M. Rusch, H. Acevedo, L. Paniagua, and M. Castro. 2009. Environmental service payments: evaluating biodiversity conservation trade-offs and costefficiency in the Osa conservation area, Costa Rica. Journal of Environmental Management 90:901911.
Benabou, R., and J. Tirole. 2003. Intrinsic and extrinsic motivation. Review of Economic Studies 70:489-520.

Bennett, M. T. 2008. China's sloping land conversion program: institutional innovation or business as usual? Ecological Economics 65:699711.

Centre for Rural Economic Research (CREC) and CJC Consulting. 2002. Economic evaluation of agri-environment schemes. Final report to the Department for Environment, Food and Rural Affairs (DEFRA). 2 September 2002. DEFRA, London, UK.

Corbera, E., K. Brown, and W. N. Adjer. 2007. The equity and legitimacy of markets for ecosystem services. Development and Change 38:587-613.

Corbera, E., C. G. Soberanis, and K. Brown. 2009. Institutional dimensions of payments for ecosystem services: an analysis of Mexico's carbon forestry programme. Ecological Economics 68:743-761.

Costanza, R., R. d'Arge, R. de Groot, S. Farber, M. Grasso, B. Hannon, K. Limburg, N. Shanid, R.V. O'Neill, J. Paruelo, R. G. Raskin, P. Sutton, and M. van den Belt. 1997. The value of the world's ecosystem services and natural capital. Nature 387:253-260.

Cowen, T., and A. Glazer. 1996. More monitoring can induce less effort. Journal of Economic Behavior and Organization 30:113-123.

Currie, J. 1994. Welfare and the well-being of children: the relative effectiveness of cash and inkind transfers. Pages 1-44 in J. M. Poterba, editor. Tax Policy and the Economy. MIT Press, Boston, Massachussets, USA.

Currie, J., and F. Gahvari. 2008. Transfers in cash and in-kind: theory meets the data. Journal of Economic Literature 46:333-383.

Deci, E.L., and R. Ryan. 1985. Intrinsic motivation and self-determination in human behavior. Springer, New York, New York, USA.

Dobbs, T. L., and J. Pretty. 2008. Case study of agri-environmental payments: the United Kingdom. Ecological Economics 65:765-775. 
Durbin, J. 2002. The potential for conservation contracts to contribute to biodiversity conservation in Madagascar. Sixteenth Annual Meeting of the Society for Conservation Biology, 14-19 July 2002, Cantebury, UK.

Ebeling, J., and M. Yasue. 2008. Generating carbon finance through avoided deforestation and its potential to create climatic, conservation and human development benefits. Philosophical Transactions of the Royal Society B: Biological Sciences 363:1917-1924.

Engel, S., S. Pagiola and S. Wunder. 2008. Designing payments for environmental services in theory and practice: an overview of the issues. Ecological Economics 65:663-674.

Engel, S., and C. Palmer. 2008. Payments for environmental services as an alternative to logging under weak property rights: the case of Indonesia. Ecological Economics 65:799-809.

Ferraro, P. J. 2001. Global habitat protection: limitations of development interventions and a role for conservation performance payments. Conservation Biology 15:990-1000.

Ferraro, P. J. 2008. Asymmetric information and contract design for payments for environmental services. Ecological Economics 65:810-821.

Ferraro, P.J., and S. K.Pattanayak. 2006. Money for nothing? A call for empirical evaluation of biodiversity conservation investments. PLOS Biology 4:105-109.

Frank, R. H. 1987. If Homo economicus could choose his own utility function, would he want one with a conscience? The American Economic Review 77:593-604.

Frey, B. S. 1993. Shirking or work morale? The impact of regulating. European Economic Review 37:1523-1532.

Frey, B. S., and R. Jegen. 2001. Motivation crowding theory. Journal of Economic Surveys 15:589-611.

Gibson, C. C., J. T. Williams, and E. Ostrom. 2005. Local enforcement and better forests. World Development 33:273-284.
Glebe, T. 2007. The environmental impact of European farming: how legitimate are agrienvironmental payments? Review of Agricultural Economics 29:87-102.

Gneezy, U., and A. Rustichini. 2000. Pay enough or don't pay at all. The Quarterly Journal of Economics 115:791-810.

Grieg-Gran, M., I. Porras, and S. Wunder. 2005. How can market mechanisms for forest environmental services help the poor? Preliminary lessons from Latin America. World Development 33: $1511-1527$.

Hanley, N. 1992. Are there environmental limits to cost-benefit analysis? Environmental and Resource Economics 2:33-59

Hardner, J., and R. Rice. 2002. Rethinking green consumerism. Scientific American 286:89-95.

Heinrich, J., R. Boyd, S. Bowles, C. Camerer, E. Fehr, H. Gintis, and R. McElreath 2001. In search of Homo Economicus: behavioral experiments in 15 small-scale societies. Economics and Social Behaviour 91:73-78.

Holmstrom, B. 1979. Moral hazard and observability. The Bell Journal of Economics 10:7491.

Holmstrom, B., and P. Milgrom. 1991. Multitask principal-agent analyses: incentive contracts, asset ownership, and job design. The Journal of Law, Economics, and Organizations 7:24.

Hughes, R., and F. Flintan. 2001. Integrating conservation and development experience: a review and bibliography of the ICDP literature. International Institute for Environment and Development (IIED), London, UK.

Kleijn, D., F. Berendse, R. Smit, N. Gilissen, J. Smit, B. Brak, and R. Groeneveld. 2004. Ecological effectiveness of agri-environment schemes in different agricultural landscapes in The Netherlands. Conservation Biology 18:775-786.

Kosoy, N., M. Martinez-Tuna, R. Muradian, and J. Martinez-Alier. 2007. Payments for environmental services in watersheds: insights from a comparative study of three cases in Central America. Ecological Economics 61:446-455. 
Laffont, J. J., and D. Martimort. 2001. The theory of incentives: the principal-agent model. Princeton University Press, Princeton, New Jersey, USA.

Landell-Mills, N., and I. T. Porras. 2002. Silver bullet or fools' gold? A global review of markets for forest environmental services and their impact on the poor. International Institute for Environment and Development (IIED), London, UK.

Levin, J. 2003. Relational incentive contracts. The American Economic Review 93:835-857.

Loomis, J., P. Kent, L. Strange, L. Fausch, and A. Covich. 2000. Measuring the total economic value of restoring ecosystem services in an impaired river basin: results from a contingent valuation survey. Ecological Economics 33:103-117.

Malcomson, J. M. 1984. Work incentives, hierarchy, and internal labor markets. The Journal of Political Economy 92:486-507.

Marland, G., K. Fruit, and R. Sedjo. 2001. Accounting for sequestered carbon: the question of permanence. Environmental Science and Policy 4:259-268.

Meijerink, G. 2008. The role of measurement problems and monitoring in PES schemes. Pages 61-85 in R. B. Dellink, and A. Ruijs, editors. Economics of poverty, environment and naturalresource use. Springer, New York, New York, USA.

Millennium Ecosystem Assessment (MEA). 2005. Ecosystems and human well-being. Island Press, Washington, D.C., USA.

Muñoz-Piña, C., A. Guevara, J. M. Torres, and J. Braña. 2008. Paying for the hydrological services of Mexico's forests: analysis, negotiations and results. Ecological Economics 65:725-736.

Musters, C. J. M., M. Kruk, H. J. De Graaf, and W. J. Ter Keurs. 2001. Breeding birds as a farm product. Conservation Biology 15(2):363-69.

Nalebuff, B. J., and J. E. Stiglitz. 1983. Prizes and incentives: towards a general theory of compensation and competition. The Bell Journal of Economics 14:21-43.

Niesten, E., P. C. Frumhoff, M. Manion, and J. J. Hardner. 2002. Designing a carbon market that protects forests in developing countries. Philosophical Transactions of the Royal Society A: Mathematical, Physical and Engineering Sciences 360:18751888.

Pagiola, S. 2008. Payments for environmental services in Costa Rica. Ecological Economics 65:712-724.

Pagiola, S., P. Agostini, J. G. Cees de Haan, M. Ibrahim, E. Murguetitio, E. Ramirez, M. Rosales, and J. P. Ruiz. 2004. Paying for biodiversity conservation services in agricultural landscapes. Environmental Department Papers. The World Bank, Washington, D.C., USA.

Pagiola, S., A. Arcenas, and G. Platais. 2005. Can payments for environmental services help reduce poverty? An exploration of the issues and the evidence to date from Latin America. World Development 33:237-253.

Pagiola, S., and G. Platais. 2002. Payments for environmental services. Environment Strategy Notes. The World Bank, Washington, D.C., USA.

Pearce, D. W., and D. Moran. 1994. The economic value of biodiversity. Earthscan, London, UK.

Peskett, L., D. Huberman, E. Bowen-Jones, G. Edwards, and J. Brown. 2008. Making REDD work for the poor. Poverty Environment Partnership, The World Bank, Washington, D.C., USA.

Pfaff, A. S. P., S. Kerr, R. F. Hughes, S. Liu, G. A. Sanchez-Azofeifa, D. Schimel, J. Tosi, and V. Watson. 2000. The Kyoto protocol and payments for tropical forest: an interdisciplinary method for estimating carbon-offset supply and increasing the feasibility of a carbon market under the CDM. Ecological Economics 35:203-221.

Pirard, R., and A. Karsenty. 2009. Climate change mitigation: should "avoided deforestation" be rewarded? Journal of Sustainable Forestry 28:434455.

Reichelderfer, K., and W. G. Bogges. 1988. Government decision making and program performance: the case of the Conservation Reserve Program. American Journal of Agricultural Economics 70:1-11. 
Robertson, N., and S. Wunder. 2005. Fresh tracks in the forest: assessing incipient payments for environmental services initiatives in Bolivia. CIFOR, Bogor, Indonesia.

Sánchez-Azofeifa, G. A., A. Pfaff, J. A. Robalino, and J. P. Boomhower. 2007. Costa Rica's Payment for Environmental Services program: intention, implementation, and impact. Conservation

Biology 21:1165-1173.

Sedjo, R. A., and S. K. Swallow. 2002. Voluntary eco-labeling and the price premium. Land Economics 78:272-284.

Simpson, R. D., and R. A. Sedjo. 1996. Paying for the conservation of endangered ecosystems: a comparison of direct and indirect approaches. Environment and Development Economics 1:241257.

Streck, C. 2004. New partnerships in global environmental policy: the Clean Development Mechanism. The Journal of Environment and Development 13:295-322.

Swallow, B., M. Kallesoe, U. Ifthikhar, M. van Noordwijk, C. Bracer, S. Scherr, K. V. Raju, S. Poats, A. Duraiappah, B. Ochieng, H. Malle, and R. Rumley. 2007. Compensation and rewards for environmental services in the developing world: framing pan-tropical analysis and comparison. International Centre for Research in Agroforestry (ICRAF) working paper No.32. World Agroforestry Center, Nairobi, Kenya.

Tietenberg, T. 2003. The tradable-permits approach to protecting the commons: lessons for climate change. Oxford Review of Economic Policy 19:400-419.

United Nations Environment Programme (UNEP), International Union for the Conservation of Nature (IUCN), and the Convention on Biodiversity (CBD). 2006. Developing international payments for ecosystem services: a technical discussion. IUCN, Geneva, Switzerland.

United States Fish and Wildlife Service (USFWS). 2009. Conservation banking: incentives for stewardship. USFWS, Washington, D.C., USA.

van de Walle, D. 1998. Targeting revisited. The World Bank Research Observer 13:231-248.
Wätzold, F., and M. Drechsler. 2005. Spatially uniform versus spatially heterogeneous compensation payments for biodiversity-enhancing land-use measures. Environmental and Resource Economics 31:73-93.

Westman, W. E. 1977. How much are nature's services worth? Science 197:960.

Wu, J. J. 2000. Slippage effects of the conservation reserve program. American Journal of Agricultural Economics 82:979-992.

Wunder, S. 2005. Payments for Environmental Services: some nuts and bolts. Occasional paper. CIFOR, Bogor, Indonesia.

Wunder, S. 2006. Are direct payments for environmental services spelling doom for sustainable forest management in the tropics? Ecology and Society 11(2): 23. [online] URL: http: //www.ecologyandsociety.org/vol11/iss2/art23/

Wunder, S. 2007. The efficiency of payments for environmental services in tropical conservation. Conservation Biology 21:48-58.

Wunder, S., S. Engel, and S. Pagiola. 2008. Taking stock: a comparative analysis of payments for environmental services programs in developed and developing countries. Ecological Economics 65:834-852.

Wünscher, T., S. Engel, and S. Wunder. 2008. Spatial targeting of payments for environmental services: a tool for boosting conservation benefits. Ecological Economics 65:822-833. 